\title{
The content of polyphenols in coffee beans as roasting, origin and storage effect
}

\author{
Katarzyna Król ${ }^{1}$ [D $\cdot$ Magdalena Gantner ${ }^{1} \cdot$ Aleksandra Tatarak $^{1} \cdot$ Ewelina Hallmann $^{1}$
}

Received: 18 July 2019 / Revised: 10 October 2019 / Accepted: 12 October 2019 / Published online: 6 November 2019

(c) The Author(s) 2019

\begin{abstract}
Coffee, one of the most popular beverages in the world, contains many bioactive compounds. The aim of this study was a comparative evaluation of the content of bioactive compounds in organic and conventional coffee (Coffea arabica) originating from Brazil during 12 months storage. The content of the polyphenolic compounds was determined using HPLC analysis. The obtained results indicate that organic or conventional production and roasting conditions (light, medium, dark roast) affect the polyphenolic compounds of coffee. The highest content of total polyphenolic compounds was determined in coffees roasted in light and medium roasting conditions. Furthermore, organic coffee beans showed higher content of bioactive compounds (total phenolic, phenolic acids and flavonoids) than conventional coffee beans. During 12 months storage a decrease in polyphenolic compounds is observed and it is connected with the degradation of chlorogenic acid, which influences total bioactivity. Moreover, the highest caffeine content was observed in light and medium roasted coffee and after storage an increase in caffeine content was observed only in organic coffee beans.
\end{abstract}

Keywords Organic farming $\cdot$ Arabica $\cdot$ Bioactive compounds $\cdot$ Storage $\cdot$ Caffeine $\cdot$ Chlorogenic acid

\section{Introduction}

The most widely cultivated species are Coffea arabica (Arabica) and Coffea canephora (Robusta). Despite the poorer sensory quality of Robusta, it has the advantage of allowing the extraction of large amounts of soluble solids, which enables its use in blends and the soluble coffee industry [1]. The coffee beverage is a rich source of bioactive compounds especially polyphenols, such as phenolic acids, mostly chlorogenic (in green beans) and caffeic (occurring after roasting). Other phenolic acids in coffee beans are: ferulic and p-coumaric. These compounds contribute to the total polyphenol intake in diet and are beneficial to consumer health $[2,3]$. Coffee is the main source of chlorogenic acid in human diet and has been cited as an efficient in vitro and ex vivo antioxidant [4]. The consumption of coffee can reduce cancers such as colon [5] and oral cancer [6], diabetes, liver disease, inhibits the oxidation of LDL

Magdalena Gantner

magdalena_gantner@sggw.pl

1 Department of Functional and Organic Food, Institute of Human Nutrition, Warsaw University Life of Sciences, 159c Nowoursynowska Str., 02-776 Warsaw, Poland cholesterol, protects against Parkinson's disease and even reduces mortality risk [7, 8]. The profile and content of bioactive compounds depend mainly on roasting parameters, which range from 160 to $240{ }^{\circ} \mathrm{C}$ and from 8 to $24 \mathrm{~min}$. The colour of beans is a main parameter to describe a degree of roasting and is classified as light, medium and dark roasted coffee [8]. During the roasting process, a decrease in polyphenolic compounds is observed and it is connected with the degradation of chlorogenic, malic and citric acid, which influences the total antioxidant activity. However, the formation of melanoidins and quinic acid during thermal process can maintain or even enhance the antioxidant capacity [9-12]. The lighter roasted coffee had the highest antioxidant activity compared to dark roasted coffee and also unroasted coffee [13]. The origin, harvesting, processing, and preparation of the beverage influence the total antioxidant activity [14]. Recently, organic food has gained higher popularity due to a demand for healthy foods and production methods.

The strict rules of organic coffee production without mineral fertilizers and pesticides give a higher food safety and quality [15]. On the other hand, plants produced under organic conditions synthetize more phenolic compounds as an effect of "self-protection" [16]. Polyphenols compounds are well known as natural pesticides for plants [17]. For 
human health polyphenols are strong antioxidants and protect against many non-infection diseases [18]. The effect of coffee brewing, grinding, origin, and roasting process on bioactive compounds has been widely studied [19-21] but there is a lack of studies concerning organic coffee production and its influence on the bioactive compounds in coffee. Therefore, this study aimed to determine the content of bioactive compounds of Coffee arabica originating from Brazilian region from organic and conventional production under varied roasting conditions (light, medium, and dark roasted beans).

\section{Material and method}

\section{Material preparation, roasting parameters, storage condition}

Green coffee beans were imported from Brazil, organic plantation was located near Coronel Fabriciano, Minas Gerias region $\left(19^{\circ} 51^{\prime} \mathrm{S} 42^{\circ} 62^{\prime} \mathrm{E}\right)$. Conventional farm was located very near to organic $\left(19^{\circ} 55^{\prime} \mathrm{S} 42^{\circ} 68^{\prime} \mathrm{E}\right)$. The amount of sample was $2 \mathrm{~kg}$ per combination. In Poland green coffee samples were subjected to roasting under the following conditions: light level: $190{ }^{\circ} \mathrm{C}$, roasting time: $25 \mathrm{~min}$; medium level: $220{ }^{\circ} \mathrm{C}$, roasting time: $25 \mathrm{~min}$; dark level: $250{ }^{\circ} \mathrm{C}$, roasting time: $25 \mathrm{~min}$. The coffee roasting equipment was: rotary oven barrel with $8 \mathrm{~kg}$ of coffee beans beaching (SpoMasz, Poland). After the roasting process, the coffee beans were vacuum-packed and brought to the laboratory for chemical analyses. One sample was divided into two groups: for "fresh analysis" just after roasting process and for "storage". Storage conditions: coffee samples in vacuum bags were stored in the following conditions: temperature $5{ }^{\circ} \mathrm{C}$, time 12 months.

\section{Dry matter}

Dry matter content was measured using the scale method (PN-EN 12145:2001) [22]. Summary: the mass of an empty glass beaker was measured on the laboratory scale. In the next step, $2 \mathrm{~g}$ of milled coffee beans was placed into a beaker, and the mass was weighted again. After $24 \mathrm{~h}$ of drying at a temperature $105{ }^{\circ} \mathrm{C}$, the samples were cooled $\left(21^{\circ} \mathrm{C}\right)$ and weighed for the third time. Based on mass difference, the content of the total dry matter in examined samples was calculated. The results are expressed as g per $100 \mathrm{~g}^{-1}$ of product.

\section{Polyphenols and caffeine}

Polyphenols were measured using the high-performance liquid chromatography (HPLC) method [23]. Before analysis, samples were ground in a coffee mill (Bosh, Germany, MKM6003), to obtain a mean particle size of $495 \mu \mathrm{m}$. One gram of milled coffee beans was extracted in $100 \mathrm{ml}$ of hot (boiled) deionized water. After $6 \mathrm{~min}$, coffee extracts were filtrated using a paper filter to a $250 \mathrm{ml}$ breaker. $1 \mathrm{ml}$ of filtered coffee was transferred to HPLC-vials and used for examination. For analysis purposes, HPLC-set-ups were used: two LC-20AD pumps, a CMB-20A system controller, a SIL-20AC autosampler, an ultraviolet-visible SPD20AV detector, a CTD-20AC oven, and a Phenomenex Fusion-RP 80A column $(250 \times 4.60 \mathrm{~mm})$, all from Shimadzu (Shimadzu, Tokyo, Japan). The gradient mobile phase contained 10\% (phase A) and 55\% (phase B) of acetonitrile and deionized water. After the mixing of acetonitrile and water in appropriate proportions, orthophosphoric (85\%) acid was added and the $\mathrm{pH}$ of the solution was measured simultaneously. After obtaining a stable value (3.0), the phases were ready to flow: $1 \mathrm{ml} \mathrm{min}^{-1}$, time program: $1.00-22.99 \mathrm{~min}$ phase A 95\% and 5\% phase B, 23.00-27.99 min-phase A $50 \%$ and $50 \%$ phase B, 28.00-28.99-min phase A $80 \%$ and $20 \%$ phase $\mathrm{B}, 29.00-38.00$-min phase A $95 \%$ and $5 \%$ phase $B$. The wavelengths used for detection were $250 \mathrm{~nm}$ for flavonoids and caffeine (quercetin-3-O-rutinoside, kaempferol-3-O-glucoside, myricetin, quercetin, quercetin-3-Oglucoside, apigenin, kaempferol) and $370 \mathrm{~nm}$ for phenolic acids (gallic, chlorogenic, caffeic, $p$-coumaric, ferulic). The phenolic compounds (quercetin-3-O-rutinoside, kaempferol-3-O-glucoside, myricetin, quercetin, quercetin-3-Oglucoside, apigenin, kaempferol, gallic, chlorogenic, caffeic, $p$-coumaric, ferulic) were identified based on Fluka and Sigma Aldrich (Poland) external standards with a purity of $99.5 \%$.

\section{Statistical analysis}

The obtained results were statistically elaborated with Statgraphics ${ }^{\circledR}$ Centurion 15.2.11.0 software (StatPoint Technologies, Inc., Warranton, VA, USA). Two-way ANOVA analysis was used. The factors within the experiment were the method of production (organic or conventional) and the level of bean roasting (light, medium, dark). The number of samples per system of production was $n=18$, and the number of samples per bean roasting was $n=6$, separately before and after storage. The lack of statistical differences $(p>0.05)$ is described in tables as not significant (NS). Different letters within a row indicate statistical differences on the level $(p<0.05)$.To obtain a clearer picture of the interrelations between the identified biologically active compounds and the level of bean roasting stage, an analysis of the main component (PCA) was used. A principal component analysis (PCA) is a handy statistical tool that applies an orthogonal transformation to convert a set of data of possibly correlated variables into a set of values of linearly uncorrelated 
variables called principal components. The PCA figures were made using Statistica 10.0 (Statsoft, Tulsa, USA). The PCA was conducted on the basis of the correlation matrix, not the covariance matrix, which corresponds to the analysis of standardized data.

\section{Results and discussion}

\section{Dry weight}

The main bioactive compounds and dry matter of fresh and stored coffee beans (C. arabica) are shown in Tables 1 and 2. The initial dry weight during storage was 97.56 and

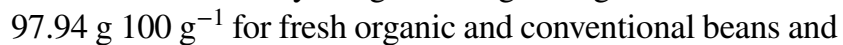

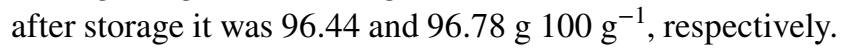
Furthermore, the roasting degrees have a significant effect on the dry weight of beans, mainly the highest content has

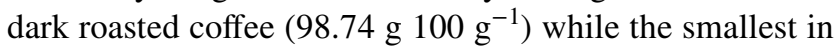

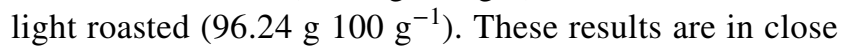
agreement with obtained results for Brazil beans reported by Dybkowska et al. [24].

\section{Caffeine}

The results of descriptive statistics showed that coffee beans from organic and conventional farming are different by caffeine content. Conventional coffee contained significantly more caffeine compared to organic one (Table 1). In conventional growing system, nitrogen fertilizer is widely used. Caffeine is purine alkaloid and nitrogen fertilization can increase the level of that alkaloid in coffee beans [25]. Not only dose but as well kind of nitrogen fertilizer could increase the level of caffeine. The easily soluble nitrogen used in conventional growing system gives an effect of caffeine increasing compare to organic one. Information about caffeine content and changes during storage in organic coffee beans is highly limited in literature; however, the higher content of caffeine in organic coffee is connected with fertilization methods, mainly organic coffee, in organic farming systems, the use of pesticides and synthetic fertilizers is completely forbidden. For pest management, caffeine (alkaloid) is a "natural pesticide" plants produce in this case, which helps to protect them against insects [26]. Furthermore, this is not surprising as coffee bean caffeine and other polyphenols content may not only be influenced by geographical location and soil physico-chemical properties, but also by bean variety, environmental factors (climate) [27] and agricultural practices (organic vs. conventional farming) [28]. During storage, the significant increase of caffeine in organic coffee was observed, to $8.55 \mathrm{mg} \mathrm{g}^{-1}$ and non-significant increase to $5.41 \mathrm{mg} \mathrm{g}^{-1}$ in conventional one. The amount of caffeine in organic stored coffee was much higher than in conventional coffee beans. The quantity of caffeine was significantly affected by the roasting degree and light roasted coffee $\left(6.42 \mathrm{mg} \mathrm{g}^{-1}\right)$ presented higher caffeine levels than medium $\left(5.77 \mathrm{mg} \mathrm{g}^{-1}\right)$ and dark roasted $\left(2.63 \mathrm{mg} \mathrm{g}^{-1}\right)$ beans. The same trend was observed for coffee beans stored

Table 1 Chemical properties of coffee from organic and conventional production (average value \pm standard deviation) for freshly roasted and stored coffee beans

\begin{tabular}{|c|c|c|c|c|c|c|}
\hline \multirow[t]{2}{*}{ Chemical parameters } & \multicolumn{2}{|l|}{ Organic coffee } & \multicolumn{2}{|c|}{ Conventional coffee } & \multicolumn{2}{|l|}{$p$ value } \\
\hline & Freshly roasted & Stored & Freshly roasted & Stored & Freshly roasted & Stored \\
\hline 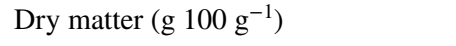 & $97.56 \pm 1.47^{\mathrm{a}, *}$ & $96.44 \pm 1.14^{\mathrm{a}}$ & $97.94 \pm 1.44^{\mathrm{a}}$ & $96.78 \pm 1.12^{\mathrm{a}}$ & N.S. & N.S. \\
\hline Caffeine $\left(\mathrm{mg} \mathrm{g}^{-1}\right)$ & $4.61 \pm 1.69^{b}$ & $8.55 \pm 3.45^{\mathrm{b}}$ & $5.26 \pm 1.97^{\mathrm{a}}$ & $5.41 \pm 2.32^{\mathrm{a}}$ & 0.0077 & $<0.0001$ \\
\hline Total polyphenols $\left(\mathrm{mg} \mathrm{g}^{-1}\right)$ & $8.95 \pm 0.77^{\mathrm{a}}$ & $1.41 \pm 0.17^{\mathrm{a}}$ & $8.28 \pm 1.16^{\mathrm{b}}$ & $1.49 \pm 0.47^{\mathrm{a}}$ & 0.0023 & N.S. \\
\hline Total phenolic acids $\left(\mathrm{mg} \mathrm{g}^{-1}\right)$ & $7.60 \pm 0.92^{\mathrm{a}}$ & $0.78 \pm 0.07^{\mathrm{a}}$ & $7.34 \pm 1.24^{\mathrm{a}}$ & $0.52 \pm 0.20^{\mathrm{b}}$ & N.S. & $<0.0001$ \\
\hline Gallic $\left(\mathrm{mg} \mathrm{g}^{-1}\right)$ & $1.45 \pm 1.00^{\mathrm{a}}$ & $0.59 \pm 0.085^{\mathrm{a}}$ & $1.17 \pm 0.57^{b}$ & $0.38 \pm 0.19^{b}$ & 0.0012 & 0.0001 \\
\hline Chlorogenic $\left(\mathrm{mg} \mathrm{g}^{-1}\right)$ & $5.94 \pm 1.45^{\mathrm{a}}$ & $0.02 \pm 0.01^{\mathrm{a}}$ & $6.00 \pm 1.83^{\mathrm{a}}$ & $0.02 \pm 0.01^{\mathrm{a}}$ & N.S. & N.S. \\
\hline Caffeic $\left(\mathrm{mg} \mathrm{g}^{-1}\right)$ & $0.058 \pm 0.07^{\mathrm{a}}$ & $0.15 \pm 0.03^{\mathrm{a}}$ & $0.050 \pm 0.07^{b}$ & $0.11 \pm 0.05^{\mathrm{b}}$ & 0.0065 & $<0.0001$ \\
\hline Salicylic $\left(\mathrm{mg} \mathrm{g}^{-1}\right)$ & $0.158 \pm 0.57^{\mathrm{a}}$ & $0.03 \pm 0.01^{\mathrm{a}}$ & $0.121 \pm 0.16^{\mathrm{a}}$ & $0.003 \pm 0.001^{\mathrm{b}}$ & 0.0013 & $<0.0001$ \\
\hline Total flavonoids ( $\mathrm{mg} \mathrm{g}^{-1}$ ) & $1.35 \pm 0.05^{\mathrm{a}}$ & $0.63 \pm 0.12^{\mathrm{b}}$ & $0.94 \pm 0.06^{\mathrm{b}}$ & $0.97 \pm 0.41^{\mathrm{a}}$ & $<0.0001$ & $<0.0001$ \\
\hline Epigallocatechin gallate $\left(\mathrm{mg} \mathrm{g}^{-1}\right)$ & $0.59 \pm 0.38^{\mathrm{a}}$ & $0.45 \pm 0.012^{\mathrm{a}}$ & $0.28 \pm 0.19^{b}$ & $0.57 \pm 0.18^{\mathrm{a}}$ & $<0.0001$ & 0.0001 \\
\hline Quercetin-3-O-rutinoside $\left(\mathrm{mg} \mathrm{g}^{-1}\right)$ & $0.103 \pm 0.06^{\mathrm{b}}$ & $0.02 \pm 0.02^{\mathrm{a}}$ & $0.156 \pm 0.06^{\mathrm{a}}$ & $0.02 \pm 0.01^{\mathrm{a}}$ & 0.0001 & N.S. \\
\hline Quercetin-3-O-glucoside $\left(\mathrm{mg} \mathrm{g}^{-1}\right)$ & $0.062 \pm 0.01^{\mathrm{a}}$ & $0.003 \pm 0.001^{\mathrm{b}}$ & $0.028 \pm 0.01^{\mathrm{b}}$ & $0.04 \pm 0.001^{\mathrm{a}}$ & $<0.0001$ & $<0.0001$ \\
\hline Kaempferol-3-O-glucoside $\left(\mathrm{mg} \mathrm{g}^{-1}\right)$ & $0.34 \pm 0.07^{\mathrm{a}}$ & $0.13 \pm 0.29^{b}$ & $0.35 \pm 0.15^{\mathrm{a}}$ & $0.29 \pm 0.29^{\mathrm{a}}$ & N.S. & $<0.0001$ \\
\hline Quercetin $\left(\mathrm{mg} \mathrm{g}^{-1}\right)$ & $0.11 \pm 0.06^{\mathrm{a}}$ & $0.03 \pm 0.02^{b}$ & $0.07 \pm 0.03^{b}$ & $0.02 \pm 0.02^{\mathrm{a}}$ & 0.0062 & 0.0135 \\
\hline Kaempferol $\left(\mathrm{mg} \mathrm{g}^{-1}\right)$ & $0.14 \pm 0.02^{\mathrm{a}}$ & $0.002 \pm 0.001^{\mathrm{b}}$ & $0.06 \pm 0.04^{\mathrm{b}}$ & $0.03 \pm 0.04^{\mathrm{a}}$ & $<0.0001$ & $<0.0001$ \\
\hline
\end{tabular}

N.S. not significant statistically

*Values followed by different small letters in the same row are significantly different $(p<0.05)$ 
Table 2 Chemical properties of coffee beans depending on roasting level and storage time (average value \pm standard deviation)

\begin{tabular}{|c|c|c|c|c|c|c|c|c|}
\hline \multirow{2}{*}{$\begin{array}{l}\text { Chemical param- } \\
\text { eters }\end{array}$} & \multicolumn{2}{|l|}{ Light } & \multicolumn{2}{|l|}{ Medium } & \multicolumn{2}{|l|}{ Dark } & \multicolumn{2}{|l|}{$p$ value } \\
\hline & Freshly roasted & Stored & Freshly roasted & Stored & Freshly roasted & Stored & Freshly roasted & Stored \\
\hline $\begin{array}{l}\text { Dry matter }(\mathrm{g} \\
\left.100 \mathrm{~g}^{-1}\right)\end{array}$ & $96.24 \pm 0.87^{\mathrm{b} *}$ & $96.97 \pm 0.83^{\mathrm{a}}$ & $98.28 \pm 1.04^{\mathrm{a}}$ & $95.89 \pm 0.67^{\mathrm{a}}$ & $98.74 \pm 0.91^{\mathrm{a}}$ & $96.98 \pm 0.92^{\mathrm{a}}$ & 0.0005 & N.S. \\
\hline Caffeine $\left(\mathrm{mg} \mathrm{g}^{-1}\right)$ & $6.42 \pm 0.22^{\mathrm{a}}$ & $8.75 \pm 0.35^{\mathrm{a}}$ & $5.77 \pm 1.13^{b}$ & $7.93 \pm 0.13^{b}$ & $2.63 \pm 0.11^{\mathrm{c}}$ & $4.26 \pm 1.03^{\mathrm{c}}$ & $<0.0001$ & $<0.0001$ \\
\hline $\begin{array}{l}\text { Total polyphenols } \\
\quad\left(\mathrm{mg} \mathrm{g}^{-1}\right)\end{array}$ & $9.45 \pm 0.51^{\mathrm{a}}$ & $1.58 \pm 0.03^{\mathrm{a}}$ & $7.95 \pm 0.18^{c}$ & $1.60 \pm 0.10^{\mathrm{a}}$ & $8.44 \pm 1.35^{\mathrm{b}}$ & $1.17 \pm 0.33^{\mathrm{b}}$ & $<0.0001$ & $<0.0001$ \\
\hline $\begin{array}{l}\text { Total phenolics } \\
\text { acids }\left(\mathrm{mg} \mathrm{g}^{-1}\right)\end{array}$ & $8.74 \pm 0.46^{\mathrm{a}}$ & $0.59 \pm 0.01^{\mathrm{b}}$ & $6.65 \pm 0.25^{\mathrm{c}}$ & $0.79 \pm 0.09^{\mathrm{a}}$ & $7.03 \pm 0.81^{\mathrm{b}}$ & $0.57 \pm 0.24^{b}$ & $<0.0001$ & 0.0006 \\
\hline Gallic $\left(\mathrm{mg} \mathrm{g}^{-1}\right)$ & $0.66 \pm 0.05^{\mathrm{b}}$ & $0.40 \pm 0.00^{\mathrm{b}}$ & $0.94 \pm 0.10^{\mathrm{b}}$ & $0.63 \pm 0.00^{\mathrm{a}}$ & $2.33 \pm 0.50^{\mathrm{a}}$ & $0.42 \pm 0.18^{\mathrm{b}}$ & $<0.0001$ & 0.0003 \\
\hline $\begin{array}{l}\text { Chlorogenic } \\
\left(\mathrm{mg} \mathrm{g}^{-1}\right)\end{array}$ & $8.00 \pm 0.46^{\mathrm{a}}$ & $0.02 \pm 0.00^{\mathrm{b}}$ & $5.56 \pm 0.46^{\mathrm{b}}$ & $0.02 \pm 0.00^{\mathrm{b}}$ & $4.35 \pm 0.37^{\mathrm{c}}$ & $0.03 \pm 0.00^{\mathrm{a}}$ & $<0.0001$ & 0.0004 \\
\hline Caffeic $\left(\mathrm{mg} \mathrm{g}^{-1}\right)$ & $0.007 \pm 0.00^{\mathrm{a}}$ & $0.16 \pm 0.00^{\mathrm{a}}$ & $0.009 \pm 0.00^{\mathrm{a}}$ & $0.12 \pm 0.02^{\mathrm{b}}$ & $0.146 \pm 0.01^{\mathrm{a}}$ & $0.11 \pm 0.07^{b}$ & N.S. & $<0.0001$ \\
\hline Salicylic $\left(\mathrm{mg} \mathrm{g}^{-1}\right)$ & $0.073 \pm 0.03^{\mathrm{c}}$ & $0.02 \pm 0.00^{\mathrm{a}}$ & $0.140 \pm 0.03^{\mathrm{b}}$ & $0.02 \pm 0.07^{\mathrm{a}}$ & $0.204 \pm 0.02^{\mathrm{a}}$ & $0.01 \pm 0.00^{\mathrm{b}}$ & $<0.0001$ & $<0.0001$ \\
\hline $\begin{array}{l}\text { Total flavonoids } \\
\left(\mathrm{mg} \mathrm{g}^{-1}\right)\end{array}$ & $0.71 \pm 0.09^{b}$ & $1.00 \pm 0.03^{\mathrm{a}}$ & $1.31 \pm 0.09^{\mathrm{a}}$ & $0.81 \pm 0.05^{\mathrm{b}}$ & $1.41 \pm 0.56^{\mathrm{a}}$ & $0.61 \pm 0.10^{c}$ & $<0.0001$ & $<0.0001$ \\
\hline $\begin{array}{l}\text { Epigallocatechin } \\
\text { gallate }\left(\mathrm{mg} \mathrm{g}^{-1}\right)\end{array}$ & $0.08 \pm 0.00^{\mathrm{b}}$ & $0.52 \pm 0.03^{\mathrm{ab}}$ & $0.64 \pm 0.18^{\mathrm{a}}$ & $0.60 \pm 0.00^{\mathrm{a}}$ & $0.57 \pm 0.35^{\mathrm{a}}$ & $0.42 \pm 0.11^{\mathrm{b}}$ & $<0.0001$ & $<0.0001$ \\
\hline $\begin{array}{l}\text { Quercetin-3-O-ruti- } \\
\text { noside }\left(\mathrm{mg} \mathrm{g}^{-1}\right)\end{array}$ & $0.053 \pm 0.03^{\mathrm{b}}$ & $0.02 \pm 0.00^{\mathrm{b}}$ & $0.155 \pm 0.06^{\mathrm{a}}$ & $0.02 \pm 0.00^{\mathrm{b}}$ & $0.180 \pm 0.02^{\mathrm{a}}$ & $0.03 \pm 0.01^{\mathrm{a}}$ & $<0.0001$ & $<0.0001$ \\
\hline $\begin{array}{l}\text { Quercetin-3- } O \text {-glu- } \\
\text { coside }\left(\mathrm{mg} \mathrm{g}^{-1}\right)\end{array}$ & $0.041 \pm 0.02^{b}$ & $0.02 \pm 0.00^{\mathrm{a}}$ & $0.049 \pm 0.00^{\mathrm{a}}$ & $0.02 \pm 0.02^{\mathrm{a}}$ & $0.046 \pm 0.04^{\mathrm{a}}$ & $0.02 \pm 0.01^{\mathrm{a}}$ & 0.0249 & N.S. \\
\hline $\begin{array}{l}\text { Kaempferol-3-O- } \\
\text { glucoside }\left(\mathrm{mg} \mathrm{g}^{-1}\right)\end{array}$ & $0.47 \pm 0.09^{\mathrm{a}}$ & $0.43 \pm 0.01^{\mathrm{a}}$ & $0.31 \pm 0.09^{b}$ & $0.14 \pm 0.02^{\mathrm{b}}$ & $0.26 \pm 0.03^{\mathrm{c}}$ & $0.06 \pm 0.04^{\mathrm{b}}$ & $<0.0001$ & $<0.0001$ \\
\hline Quercetin $\left(\mathrm{mg} \mathrm{g}^{-1}\right)$ & $0.04 \pm 0.00^{\mathrm{b}}$ & $0.01 \pm 0.00^{\mathrm{b}}$ & $0.11 \pm 0.00^{\mathrm{a}}$ & $0.03 \pm 0.02^{\mathrm{a}}$ & $0.13 \pm 0.05^{\mathrm{a}}$ & $0.03 \pm 0.01^{\mathrm{a}}$ & $<0.0001$ & $<0.0001$ \\
\hline $\begin{array}{l}\text { Kaempferol } \\
\left(\mathrm{mg} \mathrm{g}^{-1}\right)\end{array}$ & $0.03 \pm 0.01^{\mathrm{b}}$ & $0.002 \pm 0.00^{\mathrm{b}}$ & $0.04 \pm 0.00^{b}$ & $0.01 \pm 0.001^{\mathrm{a}}$ & $0.22 \pm 0.13^{\mathrm{a}}$ & $0.04 \pm 0.004$ & ${ }^{\mathrm{a}}<0.0001$ & $<0.0001$ \\
\hline
\end{tabular}

N.S. not significant statistically

*Values followed by different small letters in the same row are significantly different $(p<0.05)$

for 12 months. The results obtained by Tfouni et al. [20], Jeon et al. [29], Clarke et al. [30] showed that caffeine content is not affected by roasting degree. However, our results are in close agreement with the ones obtained by Hecimovic et al. [21] and Wanyika et al. [31], where dark roasted coffee has less caffeine than lighter roasts. Similar results of the increase in caffeine content during storage were obtained for tea samples. The explanation of these results could be the degradation of complex theaflavins and caffeine in the storage, which resulted in the dissociation and detection of caffeine [32].

\section{Total polyphenols}

According to the data shown in Tables 1 and 2 the cultivation method, roasting degree, and storage have a significant effect on the total polyphenols content in coffee beans. Organic coffee beans showed a higher content of total phenolic content $\left(8.95 \mathrm{mg} \mathrm{g}^{-1}\right)$ than conventional one $\left(8.28 \mathrm{mg} \mathrm{g}^{-1}\right)$. After 12 months of storage, the significant decrease in polyphenols was observed, $83.4 \%$ for organic coffee, and $82.9 \%$ for conventional one. Furthermore, no significant differences between conventional ( $\left.1.49 \mathrm{mg} \mathrm{g}^{-1}\right)$ and organic $\left(1.41 \mathrm{mg} \mathrm{g}^{-1}\right)$ beans were recorded. The content of polyphenols was significantly affected by the intensity of the roasting process and the highest content was observed for fresh light-roasted beans $8.74 \mathrm{mg} \mathrm{g}^{-1}$, while the lowest for medium roasted $7.95 \mathrm{mg} \mathrm{g}^{-1}$. In stored beans, the results showed that the highest content was for light roasted, and the lowest in dark roasted, 1.58 and $1.17 \mathrm{mg} \mathrm{g}^{-1}$, respectively. The presented results confirmed that the content of polyphenols may be related to the cultivation method as well as to the origin of the coffee [12]. Our results are consistent with previous reports [12, $21,24]$, wherewith increasing the degrees of roasting, the polyphenols content became considerably reduced. Katsube et al. [33] mentioned that polyphenolic compounds are highly thermolabile compounds that easily decompose under the effect of high temperature (above $80{ }^{\circ} \mathrm{C}$ ). This reduction is a result of the thermal instability during roasting of polyphenolic compounds and their degradation [1, $12,21,34]$. However, the polyphenol loss is undesirable for consumers due to beneficial effects for health. 


\section{Phenolic acids}

The total content of phenolic acids for fresh beans was higher in organic coffee $\left(7.60 \mathrm{mg} \mathrm{g}^{-1}\right)$ than in conventional beans $\left(7.34 \mathrm{mg} \mathrm{g}^{-1}\right)$, although this difference was not significant. After 12 months of storage, the significant loss of phenolic acids was observed, and the loss for organic was $90 \%$, for conventional $93 \%$, respectively. The level of phenolic acids was the highest in the lightroasted coffee, while after storage for medium roasted. The content of gallic acid was significantly higher in organic coffee (30\%). Furthermore, during roasting process, the content of gallic acid was higher, which was connected with the decomposition of chlorogenic acid. A similar trend was observed for caffeic and salicylic acids. The chlorogenic acids (CGA), which are known for their antioxidant capacities, are the main components of the phenolic fraction of coffee beans. CGA is an ester formed between caffeic acid and quinic acid and is hydrolyzed into various aromatic acid metabolites including caffeic and salicylic acid [25,35]. The initial content of chlorogenic acid was for organic coffee and conventional $5.94 \mathrm{mg} \mathrm{g}^{-1}$ and $6.00 \mathrm{mg} \mathrm{g}^{-1}$, respectively. During roasting, the levels of CGA decreased considerably, whereas the levels of caffeic and salicylic acid increased during the roasting process $(p<0.0001)$. The highest content was for the lightly roasted beans $8.00 \mathrm{mg} \mathrm{g}^{-1}$ and the smallest for the dark-roasted beans $4.35 \mathrm{mg} \mathrm{g}^{-1}$. Furthermore, Wei and Tanokura [36] investigated, that the decomposition of chlorogenic acids could be used as an index of roasting degree what is in close agreement with results obtained in this study. During 12 months of storage, the loss of CGA was observed and was on the same level $\left(0.02 \mathrm{mg} \mathrm{g}^{-1}\right)$. The decrease in CGA occurred due to enzymatic and nonenzymatic oxidation. The non-enzymatic oxidation is due to the participation reaction between enzymes (monophenolase, $o$-diphenolase, and laccase) and chlorogenic acid [37]. This is in line with the literature as high temperature during the roasting process and storage results in the loss of chlorogenic acid content, and the increase in caffeic, salicylic and gallic acid [3, 21, 34, 36, 38]. In relation to geographical origin of coffee beans, it was found that total CGA contents of Arabica green coffee beans grown in different parts of Kenya varied considerably [39]. Similar results obtained by Bertrand et al. [40] also reported variation in the concentrations of CGA in green beans grown in different regions of Colombia. The differences found between organic and conventional coffee are not only due to the different farming method, but also coffees cultivated in similar regions of the same country are genetically diverse [41].

\section{Total flavonoids}

While caffeine and CGAs represent the main components found in coffee beans, a variety of flavonoids have also been identified; however, in lower concentration. The obtained results showed that organic coffee has a significantly higher content $(p<0.0001)$ of flavonoids than conventional coffee beans. Furthermore, the flavonoid content of coffee was significantly $(p<0.0001)$ affected by the roasting degree and the higher content was observed in dark roasted beans $\left(1.41 \mathrm{mg} \mathrm{g}^{-1}\right)$. The storage time had no significant effect on the flavonoid content. However, in organic coffee beans the $53 \%$ reduction of total flavonoid was observed, in contrast to the conventional ones, where the content was on the same level. These observations are in agreement with the results previously obtained by Hecimovic [21] and Odžakovic et al. [42], which confirmed that the highest flavonoid content is in dark roasted coffee whereas the other varieties were more beneficial in light and medium roasted coffee. Otherwise, Hudakova et al. [43] reported highest content of flavonoids in unroasted coffee Arabica. In a study conducted by Lee et al. [18] it has been found that the sample roasted at lowest temperature exhibited highest total flavonoids content. Furthermore, the epigallocatechin gallate was the most abundant flavonoid in organic and conventional beans, showed the smallest decrease in the content and decrease during storage was observed only for organic coffee $(p<0.0001)$. The decrease in flavonoids content during storage was observed in the case of rutinoside-3- $O$-quercetin, glycoside3-O-kaempferol,glycoside-3-O-quercetin, quercetin, and kaempferol for every type of coffee bean. The decrease in flavonoids content suggests that it acted as an antioxidant, minimizing protein and lipid oxidation. Flavonoids content has also been investigated by Getachew and Chun [44], Kreicbergs et al. [45], where quercetin, catechin and kaempferol and their derivatives were the most abundant in coffee bean samples, what is in line with obtained results.

\section{PCA}

A principal component analysis (PCA) was performed to explain the differences between the samples of coffees in terms of storage time, roasting degree of organic and conventional coffee beans (Fig. 1). The corresponding score plot showed that the first two components describe $79.51 \%$ of the initial variability. The values of $58.71 \%$ data variance explained by the horizontal axis and $20.80 \%$ intercepted by the vertical axis, indicate that it is much more significant along the abscissa axis than along the ordinate axis. The variables on the plot showed that it is possible to group the samples according to storage time, fresh coffee beans have a positive value along the horizontal axis, while stored negative. Furthermore, for stored samples no clear 


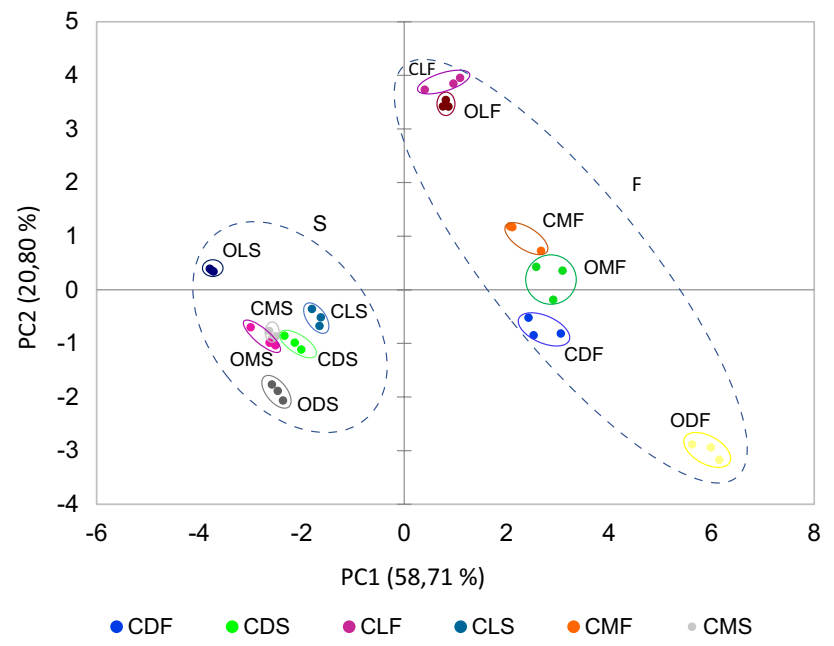

Fig. 1 PCA of relationship between storage time, roasting degree of organic and conventional coffee beans. $C$ conventional, $O$ organic, $L$ light roast, $M$ medium roast, $D$ dark roast, $F$ fresh beans, $S$ stored beans (e.g., ODF—organic, dark roasted fresh beans)

distinct clusters were obtained (among light-, medium-, and dark-roasted beans). They present the smallest diversity of variation from tested samples. However, conventional coffee beans were in the same area, thus, they had a more similar profile of bioactive compounds, than the organic coffee. In the case of fresh beans, a very effective separation between roasting degrees was observed. Light-roasted organic and conventional beans were positive along vertical and horizontal axes. Medium-roasted organic coffee showed a positive value along ordinate axis. The biggest variety in the tested group was noted for fresh dark-roasted beans, results were positive along ordinate axis and negative values were obtained along abscissa axis, which was also confirmed by the analysis of bioactive compounds described previously.

\section{Conclusion}

The obtained results indicate that coffee origin (organic or conventional) affects the polyphenolic compounds of coffee. The second hypothesis was as well confirmed. The light and medium roasting are more beneficial for preserving bioactive compounds. The quantity of caffeine was significantly affected by the roasting level. We observed, that only light roasted coffee presented the highest caffeine content. In light- and medium-roasted coffee, the content of chlorogenic acid was the highest and the smallest of chlorogenic acid derivatives. Whereas, in dark-roasted coffee flavonoids were the most abundant compounds. Fresh organic coffee beans showed a higher content of total phenolic, phenolic acids as well as flavonoids than conventional coffee beans. For the conventional beans after 12 of months storage the loss of bioactive compounds was observed and the smallest decrease in concentration was observed for epigallocatechin gallate. During the storage time, significant increase in caffeine in organic coffee was observed.

Acknowledgements This paper has been published under the support of: Polish Ministry of Higher Education within founds of Institute of Human Nutrition, Warsaw University of Life Sciences (WULS), for scientific research.

\section{Compliance with ethical standards}

Conflict of interest The authors declare that they have no conflict of interest.

Compliance with ethics requirements This article does not contain any studies with human or animal subjects.

Open Access This article is distributed under the terms of the Creative Commons Attribution 4.0 International License (http://creativeco mmons.org/licenses/by/4.0/), which permits unrestricted use, distribution, and reproduction in any medium, provided you give appropriate credit to the original author(s) and the source, provide a link to the Creative Commons license, and indicate if changes were made.

\section{References}

1. Vignoli JA, Bassoli DG, Benassi MT (2011) Antioxidant activity, polyphenols, caffeine and melanoidins in soluble coffee: the influence of processing conditions and raw material. Food Chem 124:863-868

2. Manach C, Scalbert A, Morand C, Remesy C, Jimenez L (2004) Polyphenols: food sources and bioavailability. Am J Clin Nutr 79:727-747

3. Benigno ME, Fong LE, Biju D, Muharram A, Davis IM, Vela KO, Rios D, Osorio-Camacena E, Kaur B, Rojas S, Forester SC (2018) The impact of the roast levels of coffee extracts on their potential anticancer activities. J Food Sci 83(4):1125-1130

4. Xu JG, Hu QP, Liu Y (2012) Antioxidant and DNA-protective activities of chlorogenic acid isomers. J Agric Food Chem 60:11625-11630

5. Sugiyama K, Kuriyama S, Akhter M, Kakizaki M, Nakaya N, Ohmori-Matsuda K, Hozawa A (2010) Coffee consumption and mortality due to all causes, cardiovascular disease, and cancer in Japanese women. J Nutr 140(5):1007-1013

6. Li Y-M, Peng J, Li L-Z (2016) Coffee consumption associated with reduced risk of oral cancer: a meta-analysis. Oral Surg Oral Med Oral Pathol Oral Radiol 121(4):381-389

7. Bhupathiraju S, Pan A, Malik VS, Manson JE, Willett WC, van Dam RM, Hu FB (2013) Caffeinated and caffeine-free beverages and risk of type 2 diabetes. Am J Clin Nutr 97:155-166

8. Cano-Marquina A, Tarín JJ, Cano A (2013) The impact of coffee on health. Maturitas 75:7-21

9. Somporn C, Kamtuo A, Theerakulpisut P, Siriamornpun S (2011) Effects of roasting degree on radical scavenging activity, phenolics and volatile compounds of arabica coffee beans (Coffea arabica L. cv. Catimor). Int J Food Sci Technol 46:2287-2296

10. Liu Y, Kitts DD (2011) Confirmation that the Maillard reaction is the principle contributor to the antioxidant capacity of coffee brews. Food Res Int 44:2418-2424 
11. Del Castillo MD, Gordon MH, Ames JM (2005) Peroxyl radical-scavenging activity of coffee brews. Eur Food Res Technol 221:471-477

12. Sacchetti G, Mattia CD, Pittia P, Mastrocola D (2009) Effect of roasting degree, equivalent thermal effect and coffee type on the radical scavenging activity of coffee brews and their phenolic fraction. J Food Eng 90(1):74-80

13. Cho AR, Park KW, Kim KM, Kim SY, Han J (2014) Influence of roasting conditions on the antioxidant characteristics of Colombian coffee (Coffea arabica L.) beans. J Food Biochem 38(3):271-280

14. Nunes FM, Coimbra MA (2007) Melanoidins from coffee infusions. Fractionation, chemical characterization, and effect of the degree of roast. J Agric Food Chem 55(10):3967-3977

15. Santos JS, Santos MLP, Conti MM (2010) Comparative study of metal contents in Brazilian coffees cultivated by conventional and organic agriculture applying principal component analysis. J Braz Chem Soc 21:1468-1476

16. Gordillo-Delgado F, Ernesto M, Cortés-Hernández DM, MejíaMorales C, García-Salcedo AJ (2012) Discrimination of organic coffee via fourier transform infrared-photoacoustic spectroscopy. J Sci Food Agric 92(11):2316-2319

17. Young JE, Zhao X, Carey EE, Welti R, Yang Sh-Sh, Wang W (2005) Phytochemical phenolics in organically grown vegetables. Mol Nutr Food Res 49:1136-1142

18. Lee M, McGeer EG, McGeer PL (2016) Quercetin, not caffeine, is a major neuroprotective component in coffee. Neurobiol Aging 46:113-123

19. Derrosi A, Ricci I, Caporizzi R, Fiore A, Severini C (2018) How grinding level and brewing method (Espresso, American, Turkish) could affect the antioxidant activity and bioactive compounds in a coffee cup. J Sci Food Agric 98:3198-3207

20. Tfouni SAV, Serrate CS, Carreiro LB, Camargo MCR, Teles CRA, Cipolli KMVAB, Furlani RPZ (2012) Effect of roasting on chlorogenic acids, caffeine and polycyclic aromatic hydrocarbons levels in two Coffea cultivars: Coffea arabica cv. Catuaí Amarelo IAC-62 and Coffea canephora cv. Apoatã. Int J Food Sci Technol 47:406-415

21. Hečimović I, Belščak-Cvitanović A, Horžić D, Komes D (2011) Comparative study of polyphenols and caffeine in different coffee varieties affected by the degree of roasting. Food Chem 129:991-1000

22. Polish standard. 20001. PN-EN 12145:2001. Fruit and vegetable preserves - sample preparation and methods of physicochemical tests - determination of dry matter content by gravimetric method. In: Polish standard committee, pp 1-4

23. Hallmann E, Rozpara E, Słowianek M, Leszczyńska J (2019) The effect of organic and conventional farm management on the allergenic potency and bioactive compounds status of apricots (Prunus armeniaca L.). Food Chem 279:171-178

24. Dybkowska E, Sadowska A, Rakowska R, Dębowska M, Świderski F, Świąder K (2017) Assessing polyphenols content and antioxidant activity in coffee beans according to origin and the degree roasting. Roczniki Państwowego Zakładu Higieny 68(4):347-353

25. Gonthier DJ, Witter JD, Spongberg AL, Philpott SM (2011) Effect of nitrogen fertilization on caffeine production in coffee (Coffea arabica). Chemoecology 21(3):123-130

26. Dayan FE, Cantrell ChL, Duke SO (2009) Natural products in crop protection. Bioorg Med Chem 17:4022-4034

27. Anderson KA, Smith BW (2002) Chemical profiling to differentiate geographic growing origins of coffee. J Agric Food Chem 50:2068-2075

28. Velmourougane K (2016) Impact of organic and conventional systems of coffee farming on soil properties and culturable microbial diversity. Scientifica 2016:1-9
29. Jeon JS, Kim HT, Jeon H, Hong SR, Oh MS, Park KH, Shim JH, Abd EA (2017) Determination of chlorogenic acids and caffeine in homemade brewed coffee prepared under various conditions. J Chromatogr B 1064:115-123

30. Clarke RJ, Vitzthum OG (2001) Coffee: recent developments. Blackwell Science, Hoboken (ISBN: 0-632-05553-7)

31. Wanyika HN, Gatebe EG, Gitu LM, Ngumba EK, Maritim CW (2010) Determination of caffeine content of tea and instant coffee brands found in the Kenyan market. Afr J Food Sci 4(6):353-358

32. Gao L, Liu TX (2013) Study on chemicals and antioxidant activity of Pu-er teas stored at different time. Food Ind 34:127-130

33. Katsube T, Tsurunaga Y, Sugiyama M, Furuno T, Yamasaki Y (2009) Effect of airdrying temperature on antioxidant capacity and stability of polyphenolic compounds in mulberry (Morus alba L.) leaves. Food Chem 113(4):964-969

34. Budryn G, Nebesny E, Podsędek A, Żyżelewicz D, Materska M, Jankowski S, Janda B (2009) Effect of different extraction methods on the recovery of chlorogenic acids, caffeine and Maillard reaction products in coffee beans. Eur Food Res Technol 228:913-922

35. Gonthier M-P, Verny M-A, Besson C, Rémésy C, Scalbert A (2003) Chlorogenic acid bioavailability largely depends on its metabolism by the gut microflora in rats. J Nutr 133:1853-1859

36. Wei F, Tanokura M (2015) Chapter 10 chemical changes in the components of coffee beans during roasting. In: Preedy VR (ed) Coffee health and disease prevention, Elsevier, London UK

37. Rodrigues NP, Benassi MT, Bragagnolo N (2014) Scavenging capacity of coffee brews against oxygen and nitrogen reactive species and the correlation with bioactive compounds by multivariate analysis. Food Res Int 61:228-235

38. Jaiswal R, Matei MF, Golon A, Witt M, Kuhnert N (2012) Understanding the fate of chlorogenic acids in coffee roasting using mass spectrometry based targeted and non-targeted analytical strategies. Food Funct 3:976-984

39. Gichimu BM, Gichuru EK, Mamati GE, Nyende AB (2014) Biochemical composition within Coffea arabica cv. Ruiru 11 and its relationship with cup quality. J Food Res 3:31-44

40. Bertrand B, Villarreal D, Laffargue A, Posada H, Lashermes P, Dussert S (2008) Comparison of the effectiveness of fatty acids, chlorogenic acids, and elements for the chemometric discrimination of coffee (Coffea arabica L.) varieties and growing origins. J Agric Food Chem 56:2273-2280

41. Tessesma A, Alamerew S, Kufa T, Garedew W (2011) Variability and association of quality and biochemical attributes in some promising Coffea arabica germplasm collections in southwestern Ethiopia. Int J Plant Breed Genet 5(4):1-15

42. Odžaković B, Džinić N, Kukrić Z, Grujić S (2016) Effect of roasting degree on the antioxidant activity of different Arabica coffee quality classes. Acta Scientiarum Polonorum Technologia Alimentaria 15(4):409-417

43. Hudakova J, Marcincakova D, Legath J (2016) Study of antioxidant effects of selected types of coffee. Folia Veterenaria 60(3):34-38

44. Getachew AT, Chun BS (2016) Influence of hydrothermal process on bioactive compounds extraction from green coffee bean. Innov Food Sci Emerg Technol 38:24-31

45. Kreicbergs V, Dimins F, Mikelsone V, Cinkmanis I (2011) Biologically active compounds in roasted coffee. In: Proceedings of the 6th baltic conference on food science and technology FOODBALT 2011. Innovations for food science and production, Jelgava, Latvia, pp 110-115

Publisher's Note Springer Nature remains neutral with regard to jurisdictional claims in published maps and institutional affiliations. 